\title{
The Effect of Cooperative Learning Strategies on Sixth Grade EFL Learners' Reading Performance
}

\author{
Saqr Ameen Irshaid Al Khazaleh, ${ }^{1 *}$ Awatif miz'el Abu Al Sha'r ${ }^{2}$ \\ 1- in Yarmouk university, PHD student, AL Mafraq, Jordan \\ 2- Al al-Bayt University, Professor Curriculum and Teaching - English, al Mafraq - Jordan
}

\begin{abstract}
This study aimed to investigate the effect of using cooperative learning strategies on the sixth-grade learners' reading performance and its role in enhancing their performance in English. The sample of this study were 80 male students during the second semester of the academic year 2015 \2016, at Abd Al Malek Bin Marwan Basic School for Boys in Mafraq Directorate of Education, Jordan. They were assigned randomly into two sections (One experimental and one control) in English language. The participants of the experimental group students were taught English reading activities (Read and write, read and answer, read and choose, read and match and read and put in order) through cooperative learning strategies (Jigsaw, think-pair-share, numbered heads together, round robin and round table) while the control group studied through regular teaching.

A reading activities test was used as a study instrument. Relevant statistical analyses related to means, standard deviations, and One- way MANCOVA test were used.

The results showed that teaching reading activities using cooperative learning strategies resulted in improving reading performance. Moreover, there were significant differences between the mean scores of experimental group students' performance in reading activities due to cooperative learning strategies in favor of Read and choose activity. Finally, cooperative learning strategies enhanced EFL students' performance in their reading activities.
\end{abstract}

Keywords: cooperative learning strategies, sixth grade, EFL, reading performance

DOI: $10.7176 / J L L L / 61-11$

Publication date:October $31^{\text {st }} 2019$

\section{Introduction}

Cooperative learning is defined as a set of instructional strategies "which employ small teams of pupils to promote peer interaction and cooperation for studying academic subjects." (Sharon, 1980:242).

Johnson and Johnson (1999:336) define cooperative learning as "the instructional use of small groups so that the students work together to maximize their own and each other's learning."

While working in cooperative groups, the learners not only encourage their learning but also help other group members to master the subject.

(Slavin 1988) defines cooperative learning as a set of several instructional methods in which learners master a language in small groups of 4-8. According to Slavin (1988), teachers should reward the group in terms of group performance in different ways.

"There is a difference between having students work in a group and structuring students to work cooperatively. A group of students sitting at the same table doing their own work, but free to talk with each other as they work, is not structured to be a cooperative group as there is no positive interdependence" (Johnson \& Johnson, 1988:34). It is very important to understand the difference between group work and working cooperatively. Learners can sit together but learn individually while working in groups. In cooperative learning, they work together to encourage each other to promote their own learning and that of others. In cooperative learning activities, the teachers want the group members to participate equally. (Kessler 1992:1) defines the concept of cooperative learning is "A body of literature and research that has examined the effects of cooperation in education. It offers ways to organize group work to enhance learning and increase academic achievement."

(Gillies \& Ashman 2003:13) state " Cooperative learning is well recognized as a practice that promotes learning, higher level thinking, prosocial behaviour, and a greater understanding of children with diverse learning, social and adjustment needs." 


\subsection{Background of the Study and Statement of Problem}

The history of cooperative learning started in 1966 when John Dewey claimed that education can be a tool for people to learn how to live cooperatively. After they learn how to live cooperatively, they can create a democratic society. His beliefs about education's role had an important effect on the development of cooperative learning strategies in the field of education. In (Gillies and Ashman 2003:203), the history of cooperative learning is given as follows: "One of the most influential educators of the early twentieth century was the philosopher, John Dewey. He believes that education is a process of living and that schools have a responsibility to capture children's interests, to expand and develop their horizons, and assist them in responding appropriately to new ideas and influences. Dewey's ideas are quite revolutionary at the time and they have a profound influence on education, particularly as the effects of developments in the field of group dynamics begin to be realized."

(Richards and Rodgers 2001) state that if learners work cooperatively in the classroom, this cooperation creates a positive atmosphere in which the learners' stress is reduced and motivation is increased. Cooperation also introduces a cooperative learning environment instead of a competitive environment. Both researchers point out that traditional methods in language teaching were not learner-centred and that these methods created a competitive classroom atmosphere for learners.

Cooperative learning was originally developed by David Johnson and Roger Johnson at the University of Minnesota (Harvard Education letter, 2000).

With the rise of cooperative language learning, teachers have started to apply cooperative learning while teaching the four main skills, grammar, and vocabulary in their classroom.

\subsection{Questions of the Study}

1- Are there any statistically significant differences between the mean scores of the experimental group and the control group students' reading performance at $>0.05$ due to the method of teaching (Cooperative learning strategies vs. regular instruction)?

2- Which reading activity (Read and write, read and answer, read and choose, read and match, read and put in order) did the experimental group students develop the most as a result of using cooperative learning strategies?

\subsection{Hypotheses of the Study}

This study seeks to test the following hypotheses

Ho1: There are no statistically significant differences between the mean scores of the experimental and control group on EFL learners' reading performance at $\leq 0.05$. due to the method of teaching (Cooperative learning strategies vs. regular instruction.(

Ho2: There is no reading activity (Read and write, read and answer, read and choose, read and match, read and put in order) did the experimental group students develop the most as a result of using cooperative learning strategies.

1.4 Limitation of the Study

There are limitations to the generalization of the results of the study:

- This study is limited to the sixth-grade learners who learn English at Abd Al Malek Bin Marwan Basic School for Boys in Marfaq Directorate of Education in the second semester of the academic year 2015\2016.

- This study is based on using only the cooperative learning strategies for reading activities vs. regular instruction method.

- The instrument of this study is reading activities test which measures learners' performance toward a specific topic, teaching reading activities by the cooperative learning strategies.

The sample of this study consisted only male learners at the sixth grade in Jordan -

- The duration of this study is limited to a period of 10 weeks.

- This study addressed only 5 activities (Read and write, read and answer, read and choose, read and match and read and put in order) included in Action Pack 6.

\section{Review or Related Literature}

Although there are some previous studies tackled the issue of cooperative learning, this chapter focuses on the recent studies that deal with learners' performance in reading activities. (Bayat 2004) investigated the effects of cooperative learning activities on students' attitudes towards English reading courses and cooperative learning. The sample of this study was 40 students. The study tool was a questionnaire. The results of this study revealed that cooperative learning had positive effects on students' attitudes towards English reading courses.

(Bölükbaş 2011) carried out her study to investigate the effects of cooperative learning strategies on the reading skills of students who learn Turkish as a second language. There were 40 students (20 students in experimental group and 20 students in control group). The study tool was a reading comprehension skills achievement test. In this study, it was found that cooperative learning strategies are obviously much more 
effective than traditional teaching methods.

(Al- Yaseen 2014) studied the effectiveness of cooperative learning in EFL classes. This study proved that cooperative learning strategies have lots of benefits for both teachers and students. It was also noted that the students improved their social skills as much as their language skills during the study.

(Kagan 2011) referred to the structures as step-by-step, simple activities. According to Kagan, the instructions of the structures are short, clear and easy to understand for both the teacher and the students. He also stated that Kagan structures can be used during any stage of the learning process. He also pointed out, "The structures are flexible, powerful tools which make teaching easier ensure equal participation of all group members. Whereas the roles of the group members differentiate in other cooperative learning strategies, group members' responsibilities are similar in Kagan structures. The researcher noted "Using the round table structure in place there is no need for the roles or group processing - the structure equalizes the participation; everyone participates about equally. Using Kagan's Structures radically reduces the need to assign roles and process group interaction." The instructions for the structures resemble the instructions of a game. They are fun, especially for young children. Kagan (2003) also talked about their appeal for young learners: "The Kagan Structures make teaching and learning more fun, more engaging, and more successful". Kagan structures positively affected social skills in addition to their use as a way to improve academic performance. As Davoudi \& Mahinpo (2012) indicated "Kagan structures introduce a long list of social skills, including listening, taking turns, speaking, conflict resolution skills, leadership skills, and teamwork skills. Students coming from cooperative learning classrooms are more polite and considerate of others. They can make team learning in language learning and they say their ideas and attitudes to second language." A learner-centred strategy is a major part of all Kagan structures. Teachers provide the instructions. Then they let students work in groups. During the activities, the students do all the talking and all the work. They become more engaged in the learning and more eager to learn. There have been many studies on the effect of cooperative learning on language teaching.

(Liang 2002) conducted a study on the effects of cooperative learning on EFL junior high school learners' language learning, motivation toward learning English as a foreign language, and the high- and lowachiever's academic achievements in a heterogeneous language proficiency group. The major findings of this study suggested that cooperative learning significantly enhanced the junior high school learners' oral communicative competence and their motivation toward learning English.

(Zarei and Gilani 2013) examined the effects of selected collaborative techniques on second language (L2) vocabulary comprehension and production. The researcher found out that word webbing was the most effective technique for both vocabulary comprehension and production. The findings of the present study may have theoretical as well as practical implications.

(Tekeli 2013) studied the effects of cooperative learning in developing students' writing performance and their ability to produce grammatically coherent work. The results showed that cooperative learning was effective on developing students' general writing performance and grammar skills.

(Ying Pan and Yiwu 2013) conducted a study on the effects of using cooperative learning to enhance the English reading comprehension and learning motivation of EFL freshmen in Taiwan. The sample of this study was 78 EFL freshmen. A quasi-experimental method was used in the study. The findings indicated statistically significant differences in favor of cooperative learning instruction on English reading comprehension.

(Farzaneh 2014) investigated students' attitude towards using cooperative language techniques for reading instruction. The sample of this study was 52 intermediate EFL learners (16 male and 36 female). The study tool was a survey questionnaire. The results showed that the participants generally tend towards supporting the implementation of cooperative strategies in teaching and learning reading comprehension.

(Mohammadi and Davarbina 2015) examined the effect of the cooperative learning techniques on improving the intermediate-level students' reading comprehension. The sample of this study was sixty-three participants. The study tool was a reading comprehension test. The results of one-way ANOVA demonstrated that both techniques (Jigsaw and Numbered Heads Together) of cooperative learning could improve EFL learners' reading comprehension.

(AlMuslimi 2016) studied the effect of cooperative learning strategy on English reading skills of ninth grade Yemeni students and their attitudes towards the strategy. The sample of the study 40 students. Two instruments were used (the reading comprehension test and a questionnaire). The results indicated that the students obtained higher reading comprehension scores than the control groups' scores at .05 level of significance.

(Phiwpong and Dennis 2016) focused on students' opinions towards the reading comprehension through cooperative learning activities. There were 25 students in grade 5 in Thailand. There were two instruments (the reading comprehension skill test and a questionnaire). The results of this study helped the teacher to improve teaching English by using cooperative learning strategy, promote reading comprehension, encourage and support students in reading English by using cooperative learning. 


\section{Methods and Procedures}

\subsection{Participants of the Study}

Participants of this study consisted of 80 males sixth grade students who were studying during the second semester of the academic year 2015\2016 at Abd Al Malek Bin Marwan Basic School for Boys, in Mafraq Directorate of Education in Jordan. The students' age was between 12-13 years old. The sample were divided randomly into two groups: The experimental (40 students) and the control (40 students).

\subsection{Population of the Study}

The population of the study consisted of all students enrolled on the $6^{\text {th }}$ grade in Mafraq Directorate of Education.

\subsection{Variables of the study}

The study has the following variables:

-The independent variable of this study is the methods of teaching: cooperative learning strategies (Jigsaw, think-pair-share, numbered heads together, round robin and round table) and regular instruction.

-The dependent variable is: EFL students' performance in the reading activities (Read and write, read and answer, read and choose, read and match, read and put in order).

\subsection{The Instrument of the Study}

The instrument used in this study is the reading activities test which was prepared by the researcher to measure students' performance in reading activities in English language. It included five questions; each correct answer of the questions was given 10 scores with a total of 50. The test was prepared as follows:

1- Content analysis of units 8-14 of Action Pack 6 textbook, during the academic year 2015-2016 at public schools in Jordan was made.

2- Outcomes for reading activities were identified for each unit

3- The reading activities test that included the elements of cooperative learning strategies (Jigsaw, think-pairshare, numbered heads together, round table, round robin) was prepared. The test consisted of 5 items as follows:

- Read and write

- Read and answer

- Read and choose

- Read and match

- Read and put in order

\subsection{Design of the Study}

The experiment of the study was conducted during the second semester of the academic year 2015/2016, at Abd Al Malek Bin Marwan Basic School for Boys, in Mafraq Directorate of Education, in Jordan. It lasted for 10 weeks. The aquasi-experimental design was used in the study for examining the effect of cooperative learning strategies on EFL learners' reading performance. A reading activities test was used as a study instrument. The school was selected intentionally to conduct the study. The sample of this study 80 students were assigned randomly into two groups: the experimental (40 students) and the control (40 students). The participants of the experimental group were taught reading activities in English through cooperative learning strategies, while the control group was taught through regular instruction. Both groups were taught the same material of Action Pack 6 textbook by the same teacher for the same duration. A pre-test was administered for both groups (the experimental and the control) to ensure that there is equality in their performance in reading activities. The same test was administered as a post-test after 10 weeks, and the scores were analyzed after applying the treatment to ascertain whether the cooperative learning strategies have any influence on the experimental group in learners' performance in reading activities or not.

\subsection{Validity of the Instrument}

The reading activities test was given to seven EFL university professors whose specializations were TEFL and Linguistics (Appendix B). They were asked to evaluate the test with regard to accuracy, clarity and validity of the test. They suggested wh-questions and rewrite questions. Their suggestions and comments were considered.

\subsection{Reliability of the Instrument}

The reliability of the test was verified through a pilot study of 40 students who were not included as participants of the study. The reliability coefficient of the reading activities test was calculated by using Cronbach Alpha. The test-retest was also used on the pilot study with a two-week period between the test and re-test. The reliability coefficient for the test-retest was 0.87 , which is acceptable for the purpose of this study. Two raters assessed students' answer sheets. The inter-rater reliability was 0.88 , which is statistically acceptable for the 
purpose of this study.

\subsection{Instructional Material}

The instructional material used in this study was from the Student's Book of Action Pack 6 based on cooperative learning strategies. It was prepared by the researcher. The student material included five texts taken from Action Pack 6 textbook which is prescribed for the sixth-grade students in Jordan, in the second semester of the academic year 2015-2016 Then the researcher developed the student's book. The material was taught using these cooperative learning strategies (Jigsaw, think-pair-share, numbered heads together, round robin and round table) were applied using these texts. The book also included accompanying activities related to cooperative learning strategies. Material was prepared as follows:

- Nine units were chosen from Action Pack 6 textbook.

- Outcomes for reading activities were identified for each unit.

- Cooperative learning strategies (Jigsaw, think-pair-share, numbered heads together, round robin and round table) were applied.

- The suggested material was presented to a jury of group of specialists (Appendix B) in order to decide the accuracy, clarity, validity and appropriateness of the material. Then the material was modified depending on their recommendations.

- The material was presented to the students in its final form. Table 1 shows the number of classes and the reading topics (activities).

\subsection{Instructional Treatment}

The current study was conducted during the second semester of the academic year 2015/2016. The researcher explained all details of the study to the teacher before conducting the experiment. The researcher trained the teacher how to use cooperative learning strategies. After that, the teacher explained the nature of the study and its objectives to the students.

The teacher defined and explained cooperative learning strategies (Jigsaw, think-pair-share, numbered heads together, round robin and round table) for students in the experimental group. The same teacher divided the students into heterogeneous groups of eight students each. He appointed a leader for each group. He then identified each group member a task related to one of the cooperative learning strategies whereas the teacher's role was a supervisor. The task related to the cooperative learning strategies were exchanged every reading lesson among each group members.

The teacher's role was guiding the students to use cooperative learning strategies for reading activities, giving students pieces of advice on how to apply cooperative learning strategies, solving any problem that occurred in class and answering all questions that the students had asked.

The control group participants were taught using regular instruction where the teacher managed the educational process. The same teacher taught the control group students by promoting them to read text and try to draw conclusions from reading material, extracting the main idea of the text and identifying cause and effect in reading texts. The blackboard was used in teaching reading activities by writing the main ideas of texts after reading, and understanding those texts. The teacher monitored the students in the control group as they were reading and helped them where and when needed.

\subsection{Study Procedures}

The following procedures were followed after the researcher had got the approval of Mafraq Directorate of Education to conduct the study:

1- The reading activities test was developed.

2- Validity and reliability of the reading activities test were verified.

3- The experiment was administered on sixth grade male students at Abd Al Malek Bin Marwan Basic School for Boys, at Mafraq Directorate of Education in Jordan.

4- The same teacher taught the experimental and control groups for 10 weeks.

5- After the application process, the researcher applied the reading activities pre-test renamed post-test on the control and experimental groups.

6- The data was collected and analyzed to reveal the results.

3.11 Statistical Analysis

To answer the two questions of this study, SPSS program was used. Mean scores and standard deviations of the pre-post tests were calculated for both groups: experimental and control groups. Then One-way MANCOVA test was carried out to find if there were differences between the two groups (experimental and control) on the posttest in reading performance. To find whether there were any significant differences between the mean scores of the performance of the experimental group in reading performance, a One-way MANCOVA test was used. 
4. Results of the Study

This part presents the results of the study. It consists of two parts. The first is equivalence of groups and the second is results of the study.

To find out the equivalence between the groups, means and standard deviations for pre EFL learners' performance in reading activities were calculated due to group variable, to find out whether there are statistical significant differences in these means, T-test analysis was conducted and the results are shown in Table 2.

Table 2 -: Pre-test results of T-test EFL learners' performance in reading activities scores related to group variable

\begin{tabular}{|c|c|c|c|c|c|c|c|}
\hline $\begin{array}{c}\text { Dimensions of cooperative learning } \\
\text { strategies }\end{array}$ & Group & $\mathbf{N}$ & Mean & $\begin{array}{c}\text { Std. } \\
\text { Deviation }\end{array}$ & $\mathbf{t}$ & df & $\begin{array}{l}\text { Sig. (2- } \\
\text { tailed) }\end{array}$ \\
\hline \multirow{2}{*}{ Jigsaw } & Experimental & 40 & 1.40 & 1.128 & \multirow[t]{2}{*}{$\overline{1}-342$} & \multirow[t]{2}{*}{78} & \multirow[t]{2}{*}{.184} \\
\hline & Control & 40 & 1.70 & .853 & & & \\
\hline \multirow{2}{*}{ Numbered Heads Together } & Experimental & 40 & 2.13 & 2.503 & \multirow[t]{2}{*}{.451} & \multirow[t]{2}{*}{78} & \multirow[t]{2}{*}{.653} \\
\hline & Control & 40 & 1.88 & 2.451 & & & \\
\hline \multirow{2}{*}{ Think -Pair-Share } & Experimental & 40 & 1.25 & 3.349 & \multirow[t]{2}{*}{-.321} & \multirow[t]{2}{*}{78} & \multirow[t]{2}{*}{.749} \\
\hline & Control & 40 & 1.50 & 3.616 & & & \\
\hline \multirow{2}{*}{ Round Robin } & Experimental & 40 & 2.00 & 2.481 & \multirow[t]{2}{*}{.931} & \multirow[t]{2}{*}{78} & \multirow[t]{2}{*}{.355} \\
\hline & Control & 40 & 1.50 & 2.320 & & & \\
\hline \multirow{2}{*}{ Round Table } & Experimental & 40 & 3.13 & 1.181 & \multirow[t]{2}{*}{$\overline{-} 1.230$} & \multirow[t]{2}{*}{78} & \multirow[t]{2}{*}{.222} \\
\hline & Control & 40 & 3.63 & 2.284 & & & \\
\hline \multirow{2}{*}{ Total } & Experimental & 40 & 9.90 & 4.971 & \multirow[t]{2}{*}{-.281} & \multirow[t]{2}{*}{78} & \multirow[t]{2}{*}{.780} \\
\hline & Control & 40 & 10.20 & 4.581 & & & \\
\hline
\end{tabular}

Table 2 - shows that there are no statistically significant differences $(\alpha=0.05)$ due to group variable, which means that both groups were equal in all dimensions of cooperative learning strategies and the total scores. So, both groups are equivalent in their performance.

\subsection{The First Question of the Study is ...}

Are there any statistically significant differences between the mean scores of the experimental group and the control group students' reading performance at $>0.05$ due to the method of teaching (cooperative learning strategies vs. regular instruction) on EFL learners' reading performance?

To answer this question, means, standard deviations were computed as presented in Table 3.

Table 3 -: Means, standard deviations and estimated marginal means of EFL learners' performance in reading activities according to method variable and cooperative learning strategies.

\begin{tabular}{|c|c|c|c|c|c|c|}
\hline $\begin{array}{c}\text { Dimensions of } \\
\text { cooperative learning } \\
\text { strategies }\end{array}$ & Method & Mean & $\begin{array}{c}\text { Std. } \\
\text { Deviation }\end{array}$ & $\begin{array}{c}\text { Estimated } \\
\text { Marginal Means }\end{array}$ & $\begin{array}{l}\text { Standard } \\
\text { Error }\end{array}$ & $\mathbf{N}$ \\
\hline \multirow{3}{*}{ Jigsaw post } & $\begin{array}{l}\text { Cooperative } \\
\text { learning strategies }\end{array}$ & 6.30 & 2.584 & 6.24 & .318 & 40 \\
\hline & Regular instruction & 3.90 & 1.194 & 3.96 & .318 & 40 \\
\hline & Total & 5.10 & 2.336 & 5.10 & .222 & 80 \\
\hline \multirow{3}{*}{$\begin{array}{l}\text { Numbers Heads Together } \\
\text { post }\end{array}$} & $\begin{array}{l}\text { Cooperative } \\
\text { learning strategies }\end{array}$ & 7.63 & 2.529 & 7.44 & .389 & 40 \\
\hline & Regular instruction & 3.37 & 2.628 & 3.56 & .389 & 40 \\
\hline & Total & 5.50 & 3.338 & 5.50 & .271 & 80 \\
\hline \multirow{3}{*}{ Think -Pair-Share post } & $\begin{array}{l}\text { Cooperative } \\
\text { learning strategies }\end{array}$ & 9.50 & 2.207 & 9.68 & .541 & 40 \\
\hline & Regular instruction & 3.00 & 4.641 & 2.82 & .541 & 40 \\
\hline & Total & 6.25 & 4.872 & 6.25 & .377 & 80 \\
\hline
\end{tabular}


Journal of Literature, Languages and Linguistics

ISSN 2422-8435 An International Peer-reviewed Journal

\begin{tabular}{|c|c|c|c|c|c|c|}
\hline \multirow{3}{*}{ Round Robin post } & $\begin{array}{l}\text { Cooperative } \\
\text { learning strategies }\end{array}$ & 8.13 & 2.451 & 8.23 & .346 & 40 \\
\hline & Regular instruction & 4.00 & 2.025 & 3.90 & .346 & 40 \\
\hline & Total & 6.06 & 3.050 & 6.06 & .241 & 80 \\
\hline \multirow{3}{*}{ Round Table post } & $\begin{array}{l}\text { Cooperative } \\
\text { learning strategies }\end{array}$ & 8.80 & .992 & 8.79 & .175 & 40 \\
\hline & Regular instruction & 5.75 & 1.127 & 5.76 & .175 & 40 \\
\hline & Total & 7.28 & 1.862 & 7.28 & .122 & 80 \\
\hline \multirow{3}{*}{ Total score } & $\begin{array}{l}\text { Cooperative } \\
\text { learning strategies }\end{array}$ & 40.35 & 3.317 & 40.361 & .642 & 40 \\
\hline & Regular instruction & 20.02 & 4.671 & 20.014 & .642 & 40 \\
\hline & Total & 30.19 & 10.990 & 30.188 & .454 & 80 \\
\hline
\end{tabular}

Table 3 shows a slight variance in the means of the scores according to group of each reading activities. To find out whether there are statistical significant differences in these means, one way MANCOVA was conducted for the dimensions of each cooperative learning strategy and one way ANCOVA was conducted for total score results are shown in tables 4 and 5 .

Table 4 -: One-way MANCOVA related to method variable (cooperative learning strategies vs. regular instruction) on EFL learners' reading performance dimensions.

\begin{tabular}{|c|c|c|c|c|c|c|}
\hline $\begin{array}{c}\text { Dimensions of cooperative } \\
\text { learning strategies }\end{array}$ & Dependent Variable & $\begin{array}{l}\text { Sum of } \\
\text { Squares }\end{array}$ & df & $\begin{array}{l}\text { Mean } \\
\text { Square }\end{array}$ & $\mathbf{F}$ & Sig. \\
\hline \multirow[t]{5}{*}{ Jigsaw pre } & Jigsaw post & 14.654 & 1 & 14.654 & 3.725 & .057 \\
\hline & $\begin{array}{l}\text { Numbered Heads } \\
\text { Together post }\end{array}$ & 2.219 & 1 & 2.219 & .377 & .541 \\
\hline & Think -Pair-Share post & 13.218 & 1 & 13.218 & 1.161 & .285 \\
\hline & Round Robin post & 5.698 & 1 & 5.698 & 1.226 & .272 \\
\hline & Round Table post & .132 & 1 & .132 & .111 & .740 \\
\hline \multirow{5}{*}{$\begin{array}{l}\text { Numbers Heads Together pre } \\
\text { (covariate) }\end{array}$} & Jigsaw post & 11.839 & 1 & 11.839 & 3.009 & .087 \\
\hline & $\begin{array}{l}\text { Numbered Heads } \\
\text { Together post }\end{array}$ & 49.300 & 1 & 49.300 & 8.382 & .005 \\
\hline & Think -Pair-Share post & 9.652 & 1 & 9.652 & .848 & .360 \\
\hline & Round Robin post & 17.353 & 1 & 17.353 & 3.733 & .057 \\
\hline & Round Table post & .081 & 1 & .081 & .068 & .794 \\
\hline Think -Pair-Share pre & Jigsaw post & .361 & 1 & .361 & .092 & .763 \\
\hline \multirow[t]{4}{*}{ (covariate) } & $\begin{array}{l}\text { Numbered Heads } \\
\text { Together post }\end{array}$ & .116 & 1 & .116 & .020 & .889 \\
\hline & Think -Pair-Share post & 82.936 & 1 & 82.936 & 7.285 & .009 \\
\hline & Round Robin post & .084 & 1 & .084 & .018 & .894 \\
\hline & Round Table post & .988 & 1 & .988 & .835 & .364 \\
\hline Round Robin Pre & Jigsaw post & 3.475 & 1 & 3.475 & .883 & .350 \\
\hline \multirow[t]{4}{*}{ (covariate) } & $\begin{array}{l}\text { Numbered Heads } \\
\text { Together post }\end{array}$ & 13.999 & 1 & 13.999 & 2.380 & .127 \\
\hline & Think -Pair-Share post & 39.315 & 1 & 39.315 & 3.453 & .067 \\
\hline & Round Robin post & 13.572 & 1 & 13.572 & 2.920 & .092 \\
\hline & Round Table post & .089 & 1 & .089 & .075 & .785 \\
\hline Round Table Pre & Jigsaw post & .320 & 1 & .320 & .081 & .776 \\
\hline \multirow[t]{4}{*}{ (covariate) } & $\begin{array}{l}\text { Numbered Heads } \\
\text { Together post }\end{array}$ & 17.486 & 1 & 17.486 & 2.973 & .089 \\
\hline & Think -Pair-Share post & 1.810 & 1 & 1.810 & .159 & .691 \\
\hline & Round Robin post & 25.506 & 1 & 25.506 & 5.487 & .022 \\
\hline & Round Table post & .651 & 1 & .651 & .550 & .461 \\
\hline GROUP & Jigsaw post & 98.711 & 1 & 98.711 & 25.091 & .000 \\
\hline
\end{tabular}




\begin{tabular}{|c|c|c|c|c|c|c|}
\hline $\begin{array}{c}\text { Dimensions of cooperative } \\
\text { learning strategies }\end{array}$ & Dependent Variable & $\begin{array}{l}\text { Sum of } \\
\text { Squares }\end{array}$ & df & $\begin{array}{c}\text { Mean } \\
\text { Square }\end{array}$ & $\mathbf{F}$ & Sig. \\
\hline & $\begin{array}{l}\text { Numbered Heads } \\
\text { Together post }\end{array}$ & 283.572 & 1 & 283.572 & 48.215 & .000 \\
\hline Hotelling's Trace $=8.256$ & Think -Pair-Share post & 885.751 & 1 & 885.751 & 77.805 & .000 \\
\hline \multirow[t]{2}{*}{$\mathrm{P}=.000$} & Round Robin post & 354.165 & 1 & 354.165 & 76.189 & .000 \\
\hline & Round Table post & 173.190 & 1 & 173.190 & 146.292 & .000 \\
\hline \multirow[t]{5}{*}{ Error } & Jigsaw post & 287.188 & 73 & 3.934 & & \\
\hline & $\begin{array}{l}\text { Numbered Heads } \\
\text { Together post }\end{array}$ & 429.339 & 73 & 5.881 & & \\
\hline & Think -Pair-Share post & 831.053 & 73 & 11.384 & & \\
\hline & Round Robin post & 339.340 & 73 & 4.648 & & \\
\hline & Round Table post & 86.422 & 73 & 1.184 & & \\
\hline \multirow[t]{5}{*}{ Corrected Total } & Jigsaw post & 431.200 & 79 & & & \\
\hline & $\begin{array}{l}\text { Numbered Heads } \\
\text { Together post }\end{array}$ & 880.000 & 79 & & & \\
\hline & Think -Pair-Share post & 1875.000 & 79 & & & \\
\hline & Round Robin post & 734.688 & 79 & & & \\
\hline & Round Table post & 273.950 & 79 & & & \\
\hline
\end{tabular}

Table 4 shows that there are statistically significant differences $(\alpha=0.05)$ in all dimensions of the cooperative learning strategies due to method variable in favor of cooperative learning strategies.

Table 5 -: One-way ANCOVA results related to method variable (cooperative learning strategies vs. regular instruction) on total score.

\begin{tabular}{|l|l|l|l|l|l|}
\hline \multicolumn{1}{|c|}{ Source } & Sum of Squares & df & Mean Square & \multicolumn{1}{|c|}{ F } & Sig. \\
\hline Pre-test (covariate) & 9.956 & 1 & 9.956 & .604 & .440 \\
Method & 8271.998 & 1 & 8271.998 & 501.484 & .000 \\
Error & 1270.119 & 77 & 16.495 & & \\
Corrected Total & 9542.187 & 79 & & & \\
\hline
\end{tabular}

Table 5 shows there are statistically significant differences at $(\square=0.05)$ due to method variable in favor of cooperative learning strategies.

4.2 The second question of the study is...

Which reading activity (Read and write, read and answer, read and choose, read and match, read and put in order) did the experimental group students develop the most as a result of using cooperative learning strategies?

To answer the second question of the study, means and standard deviations and of EFL learners' performance in reading activities (Read and write, read and answer, read and choose, read and match, read and put in order) were computed as presented in Table 6

Table 6 -: Means and standard deviations of the experimental group EFL learners' post-test performance in reading activities (Read and write, read and answer, read and choose, read and match, read and put in order), ranked in a descending order

\begin{tabular}{|l|l|l|l|}
\hline Rank & \multicolumn{1}{|c|}{ Activity } & \multicolumn{1}{c|}{ Mean } & \multicolumn{1}{c|}{ Std. Deviation } \\
\hline 1 & Read and choose & 9.50 & 2.207 \\
\hline 2 & Read and put in order & 8.80 & .992 \\
\hline 3 & Read and match & 8.13 & 2.451 \\
\hline 4 & Read and answer & 7.63 & 2.529 \\
\hline 5 & Read and write & 6.30 & 2.584 \\
\hline
\end{tabular}

Table 6 shows that Read and choose was ranked first rank with a mean of (9.50) followed by Read and put in order with a mean of $(8.80)$ followed by Read and match with a mean of $(8,13)$ followed by Read and answer with a mean of $(7,63)$ while Read and write was ranked last rank with a mean of $(6.30)$. 


\section{Discussion of the Results}

\subsection{Discussion of the results of the first question}

The first question investigated whether there were any statistically significant differences between the mean scores of the experimental and control groups in reading activities performance due to the method of teaching (cooperative learning strategies vs. regular instruction). The results indicated that students who were taught using cooperative learning strategies obtained the highest significant mean scores, and their reading activities performance was the best in the post-test.

The findings agreed with Liang (Kagan 2002), (Bölükbaş 2003), (Kagan 2011), (Davoudi and Mahinpo 2011), (Tekeli 2012), (Ying Pan and Yiwu 2013), (Al -Yaseen 2013) (Mohammadi 2014) (Davarbina 2015) who reported that there were significant differences in students' mean scores due to the reading performance being used in favor of students who were taught using cooperative learning strategies.

The cooperative learning strategies were based on the integration and interaction with the text, and the ability to interpret what is stated in the text in order to get the right conclusion clearly. This might contribute to the development of students' ability to acquire reading activities skills without the teachers' aid, and to increase their ability to express their opinions in an interactive learning method, including open meaningful discussion and structured dialogue channels.

The cooperative learning strategies might open the door for dialogue and discussion for students and help them to express their options in a balanced manner, in the sense that each student took his role in participation, where each student practiced the cooperative learning strategies ( Jigsaw, think-pair-share, numbered heads together, round robin and round table). At every step, students exchanged ideas and debated together. The student within the group reads a given text and did the required skill, and then analyzed and interpreted the information contained in the text. He then transferred his work to the group students, exchanged ideas to arrive at the correct reading activities. Finally, each student transmitted ideas to the other group members.

The findings of the first question also agreed with (Bayat 2004) and (Zarei \& Gilani 2013) who reported that cooperative learning had positive effects on EFL learners' attitudes towards English reading course and vocabulary comprehension and production.

\subsection{Discussion of the Results of the Second Question}

The second question investigated whether there were any significant differences between the mean scores of the experimental group students' performance in reading activities (read and write, read and answer, read and choose, read and match, read and put in order) due to strategies (Jigsaw, think-pair-share, numbered head together, round robin and round table). The results showed that Read and choose activity obtained the highest significant mean scores, and their performance were the best on the post-test in reading activities.

The result was in line with (Tekeli 2013), (Farzaneh 2014), (AlMuslimi 2016) and (Phiwpong and Dennis 2016) who suggested that cooperative learning strategies enhanced learners in reading skills and reading comprehension.

\section{Conclusion}

The following conclusions could be drawn:

1. Learning through cooperative learning strategies improved sixth grade students' reading performance.

2. Read and choose activity got the best performance in reading activities.

\section{Recommendations}

Based on the results and conclusions, the following recommendations could be adopted:

(1) Recommendations directed to the Ministry of Education

- There is a need to pay attention to introducing cooperative learning strategies in English language text-books in reading activities lessons.

- There is a need to reorganize the content of English language books by employing cooperative learning strategies in reading activities parts.

(2) Recommendations directed to the teachers

- Teachers may apply cooperative learning strategies to develop students' performance in reading activities.

- There is a need to hold training courses for teachers in order to train them to use modern methods and strategies such as cooperative learning education strategies.

(3) Recommendations directed to the researchers

- Researchers may conduct further studies which aim to examine the effect of cooperative learning strategies in reading performance.

- They may conduct studies about cooperative learning strategies teaching in reading performance to students in the other classes and stages. 


\section{Acknowledgment}

All thanks are due to Allah the Almighty for giving me the blessing and the strength to complete this work. Secondly, I would like to express my deepest thank to my supervisor, Dr. Awatif Abu Al Sha'r for her insightful comments and suggestions on earlier drafts of this study, for her assistance and valuable motherly advice and for her willing guidance and informative reviews that contributed to complete this work.Finally, my truthful thanks are to my parents for their patience and caring. Their support has been the key to my success and the fuel that kept me going

\section{References}

Al-Yaseen, W. S. (2014). "Cooperative Learning in the EFL Classroom. The 2014 WEI International Academic Conference Proceedings". Vienna: The West East Institute.

AlMusilimi ,F.K. (2016)." The Effect of Cooperative Learning Strategy on English Reading Skills of Ninth Grade Yemeni students and Their Attitudes Towards The Strategy". International Journal of Research in Humanities, 4(2),41-58.

Bayat, Ö. (2004)." The Effects of Cooperative Learning Activities on Student Attitutes Toward Reading Courses and Cooperative Learning". Ankara: Bilkent University.

Bölükbaş, F., Keskin, F., \& Polat, M. (2011). "The Effectiveness Of Cooperative Learning On The Reading Comprehension Skills In Turkish As A Foreign Language". TOJET: The Turkish Online Journal Of Educational Technology, 330-335.

Davoudi, A. H., \& Mahinpo, B. (2012). "Kagan Cooperative learning Model: The Bridge to Foreign Language Learning in the Third Millennium". Theory and Practice in Language studies, 2(6), 1134-1140. http://dx.doi.org \10.4304\tpls.2.61134-1140.

Farzaneh, N. (2014). "Students' Attitude Towards Using Cooperative Learnin for Teaching Reading Comprehension. Academic Publisher", 4(2), 287-292.

Gillies, M. R., \& Ashman, F. A. (2003). "Co-operative Learning: The social and intellectual outcomes of learning in groups". New York: RoutledgeFalmer .

Johnson, D., \& Johnson, R. T. (1999). "Learning together and alone: Cooperative, competitive, and individualistic learning "(5th ed.). Boston: Allyn and Bacon.

Kagan, S. (1999). "Cooperative Learning: Seventeen Pros and Seventeen Cons plus Ten Tips for Success". Kagan Online Magazine .

Kagan, S. (2003). "A Brief History of Kagan Structures". Kagan Online Magazine.

Kagan, S. (2003). "Kagan structures: Research and Rationale in a Nutshell. Kagan Online Magazine". Retrieved from http://www.kagan online.com〉

Kagan,S.(2011). "Kagan Structures and Learning Together- What is the difference?" Kagan Online Retrieved from http://www.kaganonline.com $\backslash$

Kessler, C. (1992). "Cooperative Language Learning A Teacher's Resource. United States of America: Prentice Hall Regents", Prentice- Hall, Inc.

Liang, T. (2002). "Implementing cooperative learning in EFL teaching: Process and Effects". Taiwan: National Taiwan Normal University.

Mohammadi, D. \& Davarbina, M. (2015) "The Effect of Cooperative Learning Techniques on Reading Comprehension ability of Iranian EFL Learners. International J". Soc. Sci. \& Education. 5(3).

Phiwpang, N., \& Dennis, N (2016). "Using cooperative Learning Activities To Enhance Fifth Greade Students' Reading Comprehension Skill". International Journal of Research - Granthaalayah, 4(1), 146-152.

Richards, J. C, \& Rodgers, T. (2001). "Approaches and methods in language teaching (2nd ed.) Cambridge", UK: Cambridge University Press.

Ying Pan, C. \& Yiwu, H.(2013). "The Cooperative Learning Effects on English Reading Comprehension and Learning Motivation of EFL Freshmen". Canadian Center of Science and education, 6 (5.)

Zarei, A. A., \& Gilani, M. S. (2013). "L2 Vocabulary Learning Through Collaborative Techniques. International Journal of Language Learning and Applied Linguistics World, 71--84. 